Review

\title{
Genetic Abnormalities in Pancreatitis: An Update on Diagnosis, Clinical Features, and Treatment
}

\author{
Mitsuyoshi Suzuki $^{1, * \mathbb{C}}$, Kei Minowa ${ }^{1}\left(\mathbb{D}\right.$, Satoshi Nakano ${ }^{1}$, Hiroyuki Isayama ${ }^{2}$ and Toshiaki Shimizu $^{1}$ \\ 1 Department of Pediatrics, Juntendo University Faculty of Medicine, Tokyo 113-8421, Japan; \\ kminowa@juntendo.ac.jp (K.M.); snakano@juntendo.ac.jp (S.N.); tshimizu@juntedndo.ac.jp (T.S.) \\ 2 Department of Gastroenterology, Juntendo University Graduate School of Medicine, Tokyo 113-8421, Japan; \\ h-isayama@juntendo.ac.jp \\ * Correspondence: msuzuki@juntendo.ac.jp
}

Citation: Suzuki, M.; Minowa, K.; Nakano, S.; Isayama, H.; Shimizu, T. Genetic Abnormalities in Pancreatitis: An Update on Diagnosis, Clinical Features, and Treatment. Diagnostics 2021, 11, 31. https://dx.doi.org/ 10.3390/diagnostics 11010031

Received: 4 November 2020 Accepted: 22 December 2020 Published: 26 December 2020

Publisher's Note: MDPI stays neutral with regard to jurisdictional claims in published maps and institutional affiliations.

Copyright: () 2020 by the authors. Licensee MDPI, Basel, Switzerland. This article is an open access article distributed under the terms and conditions of the Creative Commons Attribution (CC BY) license (https: / / creativecommons.org/ licenses/by/4.0/).

\begin{abstract}
Several pancreatitis susceptibility genes have been identified to date. A relationship between a mutation in the cationic trypsinogen (protease serine 1, PRSS1) gene and hereditary pancreatitis (HP) was first identified in 1996. Currently, HP has been defined as either two or more individuals within a family exhibiting pancreatitis for two or more generations, or pancreatitis linked to mutation of the PRSS1 gene. In 2000, a mutation in the serine protease inhibitor gene (Kazal type 1: SPINK1) was reported to be related to sporadic pancreatitis of unknown etiology. This paper reviews and summarizes the current published data on the pancreatitis susceptibility genes, mainly PRSS1 and SPINK1 genes, and introduces a diagnostic and therapeutic approach for dealing with patients with these gene mutations. Patients with these genetic predispositions, both children and adults, have often been initially diagnosed with idiopathic acute pancreatitis, in approximately $20-50 \%$ of pediatric cases and $28-80 \%$ of adult cases. In such patients, where the etiology is unknown, genetic testing, which requires pre-test and post-test genetic counselling, may prove helpful. Patients with chronic pancreatitis (CP) due to SPINK1 gene mutation and HP patients have a potentially high risk of pancreatic exocrine insufficiency, diabetes mellitus, and, of particular importance, pancreatic cancer. Thus, these patients require careful long-term follow-up and management. Specifically, symptomatic CP patients often need endoscopic therapy or surgery, often following a step-up approach beginning with endoscopic therapy and progressing to surgery if necessary, which is similar to the therapeutic approach for patients with $\mathrm{CP}$ due to other etiologies. It is important that clinicians are aware of the characteristics of patients with pancreatitis susceptibility genetic abnormalities.
\end{abstract}

Keywords: genetic mutations; chronic pancreatitis; pancreatic exocrine insufficiency; diabetes mellitus; pancreatic cancer

\section{Introduction}

When the patients with acute recurrent pancreatitis (ARP) or chronic pancreatitis (CP) showing autosomal dominant pattern of inheritance, these demographics have been characterized hereditary pancreatitis (HP). HP caused by cationic trypsinogen (serine protease 1; PRSS1) gene mutation results in ARP and CP in both children and adults with high penetrance [1,2]. Currently, HP has been defined as either, two or more individuals within a family exhibiting pancreatitis for two or more generations, or pancreatitis linked to mutation of the PRSS1 gene. On the other hand, familial pancreatitis is a border term used to describe families in which pancreatitis occurs with a greater incidence than expected by chance alone in the general population. Patients with HP usually present clinically with recurrent bouts of acute pancreatitis (AP) in the first two decades of life. HP prevalence ranges depending on the region, from 0.3 to 0.57 per 100,000 people, according to national cohort data [3-5]. Progression to $\mathrm{CP}$ occurs in the late teenage years and early adult life. As damage to the pancreas progresses, malabsorption occurs due to pancreatic exocrine insufficiency, and diabetes mellitus develops due to pancreatic islet cell damage [3]. Several 
pancreatitis susceptibility genes have been identified so far (See "History" below). The mechanisms of developing pancreatitis due to genetic abnormalities are mainly classified into three genetic pathways, classified as: the trypsin-dependent pathway, misfolding and consequent endoplasmic reticulum stress, and related to the ductal pathway [6]. Compared to the other causes of $\mathrm{ARP}$ and $\mathrm{CP}$, genetic pancreatitis has some unique clinical characteristics. Recently, several cohorts showed the natural history of patients with serine protease inhibitor gene (Kazal type 1: SPINK1) germline-related pancreatitis and HP caused by PRSS1 gene mutation, indicating a high progression rate of pancreatic exocrine insufficiency and diabetes mellitus, as well as a significantly increased risk of pancreatic cancer $[3,7]$. This paper reviews and summarizes the currently published data on the genetic abnormalities of pancreatitis susceptibility genes, and introduces a diagnostic and therapeutic approach for patients with these gene mutations.

\section{History}

In 1952, Comfort and Steinberg [8] reported CP in six members of one family over three generations. This $\mathrm{CP}$ was assumed to be due to an autosomal dominant inheritance, and was called hereditary chronic relapsing pancreatitis. Later in 1962, Gross et al. [9] evaluated $\mathrm{CP}$ in 38 patients from five families. They proposed that $\mathrm{HP}$ be defined by the following characteristics: (1) three or more patients with pancreatitis within the same family; (2) onset at a young age; and (3) pancreatitis unrelated to excessive alcohol ingestion, gallstones, or trauma. HP is due to autosomal dominant inheritance with about $80 \%$ penetrance. A relationship between a mutation in the PRSS1 gene and HP was identified in 1996 [1].

A few years before the PRSS1 gene mutation was identified, the cystic fibrosis transmembrane conductance regulator (CFTR) gene, a causative gene of cystic fibrosis [10], was also reported to be a gene associated with ARP and CP [11,12]. In 2000, a mutation in the serine protease inhibitor gene (Kazal type 1: SPINK1) was reported to be related to chronic idiopathic pancreatitis of unknown cause [13]. Since then, genetic causes of pancreatitis, calcium-sensing receptor (CASR) in 2003 [14-17], chymotrypsin C in 2008 (CTRC) [18], claudin-2 (CLDN2) in 2012 [19], carboxypeptidase A1 (CPA1) in 2013 [20], carboxyl ester lipase (CEL) in 2015 [21], chymotrypsin B1 and B2 (CTRB1/CTRB2) in 2017 [22], pancreatic lipase (PNLIP) in 2019 [23], and transient receptor cation channel subfamily V member 6 gene (TRPV6) in 2020 [24] have also been reported to play key roles in the etiology of APR and CP. With respect to these genes, p.C563fsX673 and p.C596fsX695 in CEL gene [25], and p.S282P in CAP1 gene [26] have also been determined as causative factors of $\mathrm{HP}$, together with PRSS1 gene. Conversely, PRSS2 p.G191R variants, reported in 2006, mitigate intra-pancreatic trypsin activity and thereby protect against CP [27].

\section{Evaluation of the Causes of ARP and CP}

Alcohol abuse is a well-known risk factor for $\mathrm{CP}$ in adults, and thus this etiology accounts for more than $60 \%$ of cases of CP in adults [28]. However, only $2-5 \%$ of heavy drinkers develop $\mathrm{CP}$, and it is assumed that not only alcohol, but also other factors such as genetic background are involved in a complex manner. A positive association between smoking tobacco and developing pancreatitis has also been recognized, independently of alcohol [29]. In children, the etiology is often drugs, infections, trauma, and anatomic anomalies, such as choledochal cysts and pancreaticobiliary maljunction [30-32].

Patients with these genetic predispositions, both children and adults, have often been initially diagnosed with idiopathic AP; in approximately $20-50 \%$ of pediatric cases $[2,33]$ and $28-80 \%$ of adult cases [34]. In these ARP and CP patients, for whom the etiology is unknown, genetic testing may prove helpful (Figure 1). Genetic testing should be considered in patients who fulfill one or more of the criteria listed in Table $1[35,36]$. According to the European Registry of Hereditary Pancreatitis and Familial Pancreatic Cancer (EUROPAC), a diagnosis of $\mathrm{HP}$ can be made without genetic testing if the patient has both a personal history of pancreatitis and APR, or has CP been diagnosed in two first-degree relatives or in three or more second-degree relatives, spanning at least two generations [37]. Patients 
who undergo genetic testing should have genetic counseling prior to, and after, testing [36]. Unfortunately, even if pancreatitis-related genetic abnormalities are discovered at this time, there is no radical cure, such as gene therapy. However, proper diagnosis would also motivate patients and their families to continue treatment. Germline testing, currently for recommended etiologic mutations associated with pancreatitis, includes evaluation for pathogenic variants in the CEL, CFTR, CPA1, CTRC, PRSS1, and SPINK1 genes in symptomatic individuals [29]. Asymptomatic testing can be considered in patients with first-degree relatives with known causative gene mutations, but it should be performed in the context of genetic counseling [36].

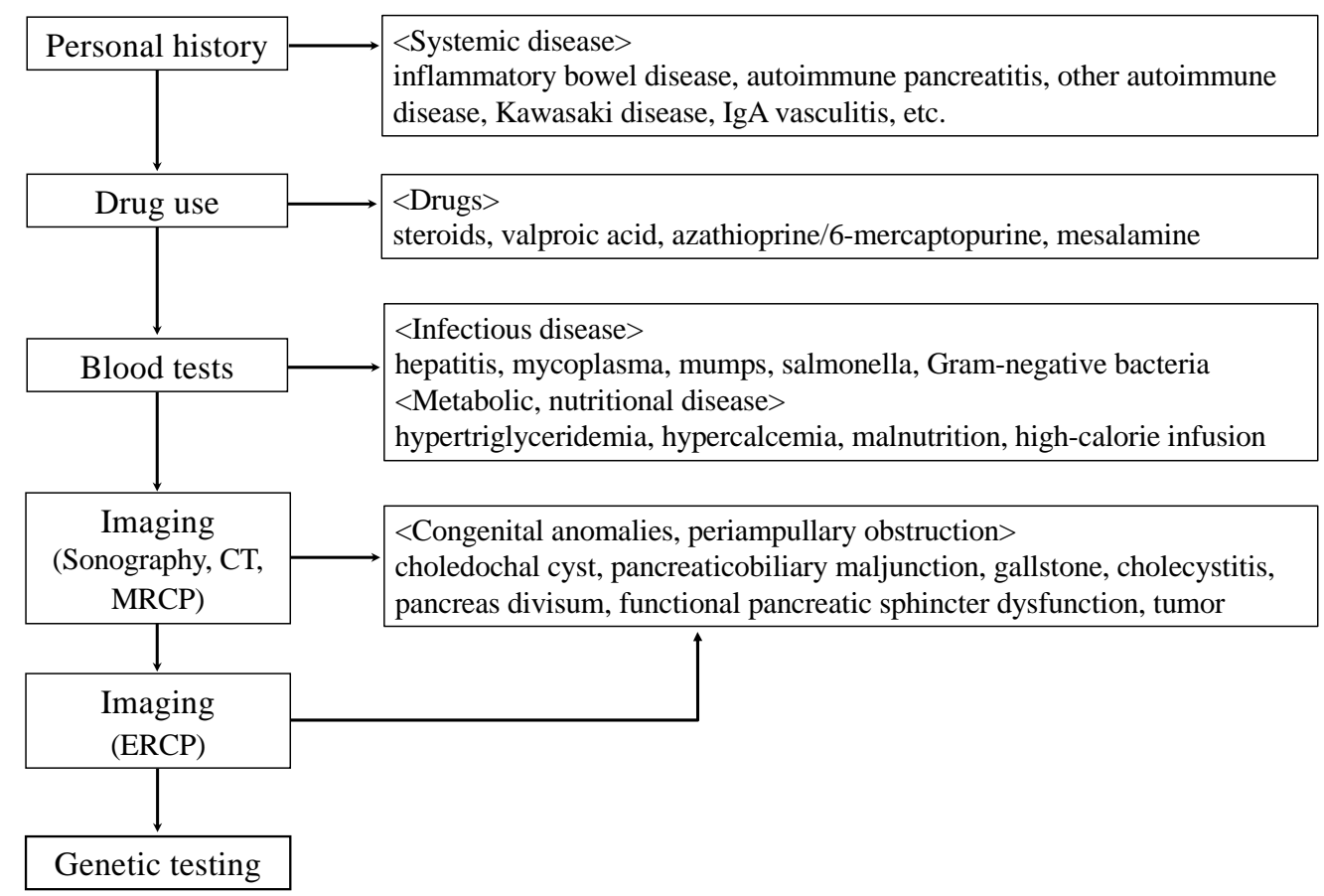

Figure 1. Identifying the cause of childhood acute pancreatitis (AP), acute recurrent pancreatitis (ARP), and chronic pancreatitis (CP).

Table 1. Criteria for genetic testing for hereditary pancreatitis.

\begin{tabular}{cl}
\hline Consider When Patients Meet One or More of the Following Criteria: \\
\hline 1 & A family history of idiopathic CP, ARP, or childhood pancreatitis \\
2 & Relatives with known mutations associated with HP \\
3 & Unexpected pancreatitis in a child \\
4 & Idiopathic CP in patients < 25 years old \\
5 & ARP of uncertain etiology \\
6 & Patients who meet criteria for participation in approved research projects \\
\hline HP: hereditary pancreatitis, CP: chronic pancreatitis, ARP: acute recurrent pancreatitis.
\end{tabular}

Clarifying the medical and personal history allows identification of the cause of pancreatitis, such as systemic diseases, drugs, and infectious diseases. Subsequent imaging studies, such as sonography, computed tomography (CT), and/or magnetic resonance cholangiopancreatography (MRCP), can detect anatomic anomalies and obstruction in the pancreaticobiliary system. Since MRCP has a low sensitivity for identifying pancreaticobiliary maljunction in young patients below about 2 years of age [38], MRCP should be repeated after a while or endoscopic retrograde cholangiopancreatography (ERCP) should be performed as necessary. 


\section{Genetic Abnormalities}

\subsection{CFTR Gene}

The CFTR gene has been identified as a causative gene of cystic fibrosis [10], and it is also reported to be a gene associated with pancreatitis $[11,12]$. About $1-4 \%$ of the overall cystic fibrosis population will have an episode of pancreatitis. Mutation causes a defect in the CFTR protein that causes abnormal $\mathrm{HCO}_{3}{ }^{-}$transport, leading to defective pancreatic secretion [39]. As a result of impaired pancreatic juice alkalinization and water secretion, protein plugs form in the pancreas and/or pancreatic duct [40]. Regarding the relationship with $\mathrm{CP}$, it has been reported that splicing efficiency and channel function decrease due to poly T polymorphism, TG repeat polymorphism, and p.Q1352H polymorphism $[11,12,41]$. Some CFTR mutations can be inherited in a complex-type pattern. The CFTR gene is considered to be a high-risk for developing $\mathrm{CP}$ when it is associated with other multiple mutations (complex heterozygotes mutation), especially SPINK1 gene mutations [42-44].

\subsection{PRSS1 Gene}

Mutations in PRSS, which encodes cationic trypsinogen, the most abundant isoform of trypsinogen in human pancreatic juice, can occur. In 1996, the p.R122H in the PRSS1 gene was first identified as a cause of HP [1]. In the following years, the p.N29I mutation was detected as a new mutation in HP patients [45]. The p.R122H mutation is the most common ( $65 \%)$, followed by p.N29I mutation $(\sim 25 \%)$, and p.A16V. Increased trypsin levels are generated at the onset of pancreatitis, but not through the same biological mechanism. The p.R122H mutation (autolysis site) inhibits trypsin self-destruction, following increased trypsin stability and high level of trypsin in the pancreas, leading to pancreatic autodigestion and pancreatitis [46]. The p.A16V mutation (activation site) increases $\mathrm{N}$-terminal processing of the trypsinogen activation peptide by CTRC, which in turn enhances autoactivation [46,47]. The p.N29I mutation affects both degradation and autoactivation in trypsinogen biochemistry [46].

Alternatively, a subset of PRSS1 mutations can cause misfolding and endoplasmic reticulum stress [48]. In 2009, the p.R116C mutation found in HP families with incomplete penetrance was first reported as a cause of $\mathrm{CP}$ by a mis-folding-dependent pathway. Since then, several variants such as p.D100H, pC139F, p.K29N, p.S124F, and p.G208A have been reported, likely involving this pathway, but the detailed pathogenic mechanism is still unclear [49].

\subsection{SPINK1 Gene}

SPINK1 encodes a pancreatic secretory trypsin inhibitor, and mutations interfere with the protective function, and predispose a person to pancreatitis, possibly via increased intrapancreatic trypsin activity. SPINK1, together with the protease inhibitors $\alpha_{1}$-antitrypsin and $\alpha_{2}$-macroglobulin, binds to activated trypsin and inhibits its activity. SPINK1 inhibits about $20 \%$ of total trypsin activity, and acts as a primary defense mechanism [50,51]. The trypsin binding site is encoded on exon 3. The most common mutation is the p.N34S mutation. According to the first repot by Witt et al., the p.N34S variant was found in $18 / 85$ (21\%) of children with idiopathic pancreatitis [13]. However, the p.N34S mutation is even present in $0-2 \%$ of otherwise healthy persons, suggesting that this mutation is thought to be a disease-modifying factor rather than causative factor, when additional risk factors for pancreatic inflammation such as alcohol, tobacco consumption, or genetic are present $[51,52]$. Actually, the p.N34S variation had no effect on the secretion of SPINK1 protein from transfected cells and trypsin inhibitory activity of the mutant protein was also unchanged [53,54]. Recently, the p.N34S mutation was found in $20 \%$ of patients carrying the functionally defective TRPV6 variants [24], suggesting that the combination of mutated TRPV6 and SPINK1 p.N34S results in predisposition to pancreatitis, as well as the CFTR gene. The next most frequent mutation is the c.194 + 2T >C mutation, which has often been reported in Asian persons in Japan, China, and South Korea [55-57]. In the c.194 + 2T > C 
mutation, because exon 3 is skipped, due to a slicing aberration, trypsin activation cannot be inhibited, and pancreatitis occurs [58].

\subsection{CTRC Gene}

Following the finding that CTRC specifically degrades trypsin, the association between CTRC mutations and pancreatitis was investigated [18]. CFTR mutations have been shown to occur in $0.7 \%$ of healthy controls and $2.9 \%$ of adults with CP [18]. In a recent cohort from the International Study Group for Pediatric Pancreatitis: In Search of a Cure (INSPPIRE), it was reported that early-onset pancreatitis below 6 years of age was likely associated with genetic abnormalities, particularly PRSS1 (43\%) or CTRC (14\%) mutations [2]. CTRC serves as a second lone defense against premature activation of trypsinogen isoforms [18]. Mutations of CTRC cause loss of function by several mechanisms, which include severe reduction of CTRC secretion (p.A73T), inactive CTRC (p.K247_R254del), promotion of degradation by trypsin (p.R254W), decreased CTRC activity (p.V235I), or decreased CTRC mRNA (p.G60 =) $[18,59,60]$. Of note, only CTRC pathogenic variants do not seem to cause $\mathrm{CP}$, but rather they are seen in combination with other variants, such as CTRC or SPINK1 mutations $[18,43,60]$, or with anatomic anomalies of the pancreaticobiliary system $[33,61]$.

\subsection{CPA1 Gene}

The mechanism by which a CPA1 mutation confers an increased risk of pancreatitis involves misfolding-induced endoplasmic reticulum stress, rather than increased trypsin activity [20]. CPA1 mutations with less than $20 \%$ apparent activity of the CPA1 protein have been observed to be significantly overrepresented in patients with $\mathrm{CP}$. The functionally impaired CPA1 variants with less than $20 \%$ functionality were found in $3.1 \%$ of nonalcoholic CP patients $(29 / 944)$ and $0.1 \%$ of controls $(5 / 3938)(p<0.01)$. The most frequent functionally impaired variant was p.N256K, and it was observed in $0.7 \%(7 / 944)$ of patients and $0 \%(0 / 3938)$ of controls. The risk for pancreatitis was 38 -fold greater in patients younger than 20 years old and 84-fold greater in patients younger than 10 years old. The associations between CPA1 mutations and non-alcoholic CP patients have also been reported in additional cohorts from Europe $(1.3 \%(8 / 600)$ and $0.4 \%(9 / 2432)(p<0.01))$, India $(2.5 \%(6 / 239)$ and $0.3 \%(1 / 340)(p<0.05))$, and Japan $(2.0 \%(5 / 247)$ and $0 \%(0 / 341)$ $(p<0.05))[20]$

\subsection{TRPV6 Gene}

TRPV6 is a member of the transient receptor potential vanilloid ion channel superfamily [62]. TRPV6 promotes high $\mathrm{Ca}^{2+}$ entry in absorptive and secretory tissues. It is mainly expressed in $\mathrm{Ca}^{2+}$-transporting epithelia. In the pancreas, TRPV6 expression is nearly 6-times higher in ductal cells than in acinar cells [63]. More recently, Masamune et al. reported that impaired $\mathrm{Ca}^{2+}$ uptake caused by TRPV 6 variants was associated with early-onset CP [24]. Interestingly, 6 out of 30 (20\%) patients with functionally defective TRPV6 variants were trans-heterozygous for SPINK1 p.N34S [24], indicating that CP is a complex multigenic disease, and a cumulative genetic handicap seems to be crucial for the development of early-onset CP.

\subsection{Others}

CASR, first characterized in the bovine parathyroid [64], expressed in the pancreas can respond to high calcium concentrations in the pancreatic juice by increasing ductal fluid secretion, thereby preventing stone formation and pancreatitis [65]. An association between developing CP and variants in the CASR gene has been reported [14-17], but the evidence remains uncertain.

PRSS2 is another major trypsinogen isoform constituting the bulk of secreted trypsinogen in humans [66]. No pathogenic PRSS2 variants have been identified in HP and sporadic pancreatitis [27]. The variant p.G191R introduces a trypsin cut site anionic trypsin, which 
reduces the overall activity of $P R S S 2$, indicating that this variant confers protection from CP [27].

CLDN2 is expressed in the proximal pancreatic duct and promotes $\mathrm{H}_{2} \mathrm{O}$ and $\mathrm{Na}^{+}$ transport to counter $\mathrm{Cl}^{-}$and $\mathrm{HCO}_{3}{ }^{-}$secretion through CFTR [19]. CLDN2 mutations, an $X$-chromosome locus gene, were found to be associated with alcohol-related and sporadic pancreatitis [19]. Since men are hemizygous for the $X$ chromosome, the risk appears dominant, whereas it is inherited as a recessive pattern in women.

Mutations in CEL cause maturity-onset diabetes of the young type 8 (MODY8), as well as pancreatic exocrine dysfunction [25]. A hybrid CEL allele (CEL-HYB1), formed by nonallelic homologous recombination between CEL and its adjacent pseudo-gene CELP, was enriched approximately 5-fold in patients with idiopathic CP [21]. This hybrid protein was poorly secreted due to intracellular retention, leading to endoplasmic reticulum stress and apoptosis in an in vitro experiment [21].

The changes in the balance of chymotrypsin isoforms, namely inversion at the CTRB1 and CTRB2 locus, that affect trypsin degradation slightly increased the risk of alcoholic and non-alcoholic CP [22,67]. In addition, several variants of PNLIP gene, particularly p.F300L, were associated with early onset and non-alcoholic CP in the European population, but the mechanism remains unclear [23].

\section{Clinical Features of PRSS1 and SPINK1 Gene Mutation-Related Pancreatitis}

\subsection{Age at Symptom Onset, Pancreatic Exocrine Insufficiency, and Diabetes Mellitus}

$\mathrm{ARP}$ is frequently a precursor to $\mathrm{CP}$, and both are thought to be on the same disease continuum. In particular, genetic factors are associated with early progression of ARP to CP $[5,24,37,68]$. Most patients developed their first symptoms before they were 30 years old. HP patients are known to have a higher future risk of developing pancreatic exocrine insufficiency and diabetes mellitus [2]. In the EUROPAC study that enrolled 418 HP patients in 112 families (52\% families had the PRSS1 p.R122H, 21\% had the PRSS1 p.N29I, and 19\% had no PRSS1 mutations) [37], the median age at symptom onset was 10 years in p.R122H, and 14 years in p.N29I. Pancreatic exocrine insufficiency and diabetes mellitus developed in $37 \%$ and $48 \%$ of patients at 50 years of age, and $60 \%$ and $70 \%$ at 70 years of age, respectively. The average age from onset to pancreatic exocrine insufficiency and diabetes mellitus was as long as 53 years. In a French study that enrolled $200 \mathrm{HP}$ patients in 78 families, PRSS1 mutations were found in 68\% (p.R122H 78\%, p.N29I 12\%, others 10\%), and the median age at first symptom onset was 10 years [5]. Pancreatic exocrine insufficiency developed in 34\% of patients (median age of occurrence, 29 years), and diabetes mellitus in $26 \%$ of patients (median age of occurrence, 38 years) [5].

Previous studies have assessed the association between mutation type and disease phenotype [37], but the results were inconsistent. A recent Japanese nationwide survey enrolled $271 \mathrm{HP}$ patients from 100 families (PRSS1 p.R122H 33\%, PRSS1 p.N29I 8\%, SPINK1 p.N34S 22\%, SPINK1 c.194 + 2T > C 14\%, SPINK1 p.P45S 1\%) and showed that the mean age at symptom onset was 12.3 years in patients with PRSS1 mutations, and 20.0 years with SPINK1 mutations [3]. The cumulative rates of pancreatic exocrine insufficiency and diabetes mellitus in both patients with PRSS1 and SPINK1 mutations were $16.1 \%$ and 5.5\% at 20 years of age, and $45.3 \%$ and $28.2 \%$ at 40 years of age, respectively [3]. In this survey, $\mathrm{HP}$ was defined in ARP and/or CP patients with a family history of two or more affected patients, irrespective of generation, with at least one of the patients having an unknown etiology, and in the case of siblings only, age at onset before 40 years was needed to define HP [3]; thus, patients with SPINK1 gene mutations could be included in the category of HP.

More recently, Muller et al. [7] focused only on 209 patients with SPINK1 mutations, and reviewed their prognosis. The median onset of symptoms was 20.1 years. The cumulative rates of pancreatic exocrine insufficiency and diabetes mellitus were 5.3\% and $7.8 \%, 14.7 \%$ and $13.4 \%, 28.3 \%$ and $26.3 \%, 52.4 \%$, and $43.4 \%$ at $30,40,50$, and 60 years of age, respectively [7]. These results supported the concept that patients with PRSS1 mutations developed pancreatic exocrine insufficiency and diabetes mellitus earlier than 
those without PRSS1 or SPINK1 mutations; thus, PRSS1-associated HP patients show severe phenotypes.

\subsection{Pancreatic Cancer}

It is well known that CP patients with PRSS1 or SPINK1 gene mutations belong to a high-risk group for pancreatic cancer, with an estimated risk 53-87 times higher than the normal population $[37,69,70]$. In the EUROPAC study, the overall cumulative risk of pancreatic cancer was $0 \%$ to 30 years, $0.5 \%$ at 40 years of age, $3.4 \%$ at 50 years, $9.8 \%$ at 60 years, $18.8 \%$ at 70 years, and $33.3 \%$ at 80 years [37]. In a French cohort of HP patients, the cumulative rates of pancreatic cancer diagnosis at 50,60 , and 75 years of age were $10.0 \%$, $18.7 \%$, and $53.5 \%$, respectively [69]. In a recent Japanese HP cohort, the cumulative rates at 40,60 , and 70 years of age were $2.8 \%, 10.8 \%$, and $22.8 \%$, respectively [3]. From the data of a cohort focused on patients with SPINK1 mutations, the cancer risk was 12-times higher in patients than in controls, and the cumulative rates of pancreatic cancer before 50, 60, 70 , and 80 years of age were $0.8 \%, 11.9 \%, 27.7 \%$, and $51.8 \%$, respectively [7]. Overall, the cumulative rates of pancreatic cancer at $40,50,60,70$, and 80 years of age were $0.5-2.8 \%$, $0.8-10.0 \%, 9.8-18.7 \%, 7.2-40.0 \%$, and $33.3-51.8 \%$, respectively. Thus, development of pancreatic cancer was not restricted to PRSS1-asociated HP, but was also found in patients with SPINK1 germline mutations, suggesting that long-term inflammation and existing $\mathrm{CP}$ involving hyperplasia and metaplasia of the pancreatic duct epithelium, not the mutations alone, increase the risk of pancreatic cancer.

\section{Treatment}

Patients with genetic abnormalities are usually managed in the same way as patients who present with AP, ARP, and CP of other etiologies. The initial treatment for AP is to withhold oral intake of food or fluid to prevent stimulation of pancreatic exocrine secretions, allowing the pancreas to rest. Fluid and electrolyte supplementation and treatment to relieve pain and prevent infection are provided. AP is known to be associated with the activation of clotting and the degree of this activation is closely related to the severity of AP [71,72]. Heparin in complex with antithrombin prevents coagulation by inhibiting proteases involved in the coagulation cascade, such as activated forms of factor XII, XI, IX, $\mathrm{X}, \mathrm{VII}$, and thrombin [73]. Furthermore, heparin directly and indirectly inhibits the activity of pancreatic digestive enzymes, such as trypsin and chymotrypsin [74,75], as well as inhibiting the conversion of trypsinogen to active trypsin [76]. Considering the mechanism of developing pancreatitis due to PRSS1 mutations, these data suggest that anticoagulants, especially heparin, may be useful in the prevention and/or treatment of HP.

Symptomatic CP patients often require endoscopic treatment or surgery. Endoscopic treatments were performed in $16.0 \%(32 / 200)$ [5] and $22.6 \%(35 / 155)$ [3] of HP patients. Surgical procedures were required in $19.4 \%$ (81/417) [37], 16.0\% (32/200) [5], and $17.4 \%$ $(27 / 155)$ [3] of HP patients. In the EUROPAC study, the cumulative risk of pancreatic resection was $0.6 \%$ to 10 years of age, $2.5 \%$ at 20 years, $8.3 \%$ at 30 years, $11.4 \%$ at 40 years, $17.5 \%$ at 50 years, and $21.5 \%$ at 70 years [37]. Only a cohort from Japan showed the cumulative risks of both endoscopic treatment and surgical procedures, which were $2.0 \%$ and $2.8 \%$ at 10 years of age, $12.3 \%$ and $10.1 \%$ at 20 years, $29.0 \%$ and $25.2 \%$ at 40 years, and $43.0 \%$ and $28.1 \%$ at 60 years, respectively [3]. Recently, the effectiveness of total pancreatectomy with autotransplantation (TPIAT) has been well described in both adults and children with CP unresponsive to medical and endoscopic treatments [77-79]; which is also more likely to be performed if underlying genetic risk has been demonstrated [77,78].

Currently, since endoscopic therapy of CP is an effective treatment in adults, and the evidence of its efficacy for pediatric populations has been growing [80,81], a step-up strategy has become increasingly standard and more commonly applied for the treatment of both adult and pediatric CP patients [82-84]. This strategy starts with endoscopic treatment and progresses to surgery if endoscopic therapy fails or proves technically impossible [84]. Treatment involves endoscopic retrograde cholangiopancreatography with pancreatic 
sphincterotomy, pancreatic stent placement, and stone removal. Various ingenious techniques and devices have been developed for endoscopic treatment, such as multiple plastic stents placement or fully-covered self-expandable metallic stent placement [85-87].

Pediatric cases of SPINK1 germline mutation-related CP who underwent endoscopic treatment are shown in Figure 2. An 8-year-old girl, with compound heterozygous for SPINK1 p.N34N/S and c.194 + 2T > C mutations, suffered from recurrent pancreatitis with main pancreatic duct dilation (Figure 2a). Endoscopic pancreatic stenting with a 7 Fr plastic stent was performed across the minor papilla after sphincterotomy to prevent recurrent pancreatitis. Major papilla cannulation failed because of pancreas divisum, or obstruction of Wirsung's duct due to chronic inflammation. To resolve the pancreatic ductal stricture, multiple plastic stents placement was planned, by exchanging the plastic stent about every 3 months, gradually increasing the size and number of plastic stents, two times $(7 \mathrm{Fr}+5 \mathrm{Fr})$ and two times $(7 \mathrm{Fr}+7 \mathrm{Fr}+5 \mathrm{Fr})($ Figure $2 \mathrm{~b}, \mathrm{c})$. Multiple plastic stents were successfully removed with improvement of the main pancreatic duct stricture 18 months after the initial stenting. The main pancreatic duct dilation was improved, confirmed by magnetic resonance cholangiopancreatography, without episodes of recurrent pancreatitis 16 months after the stent removal (Figure 2d).
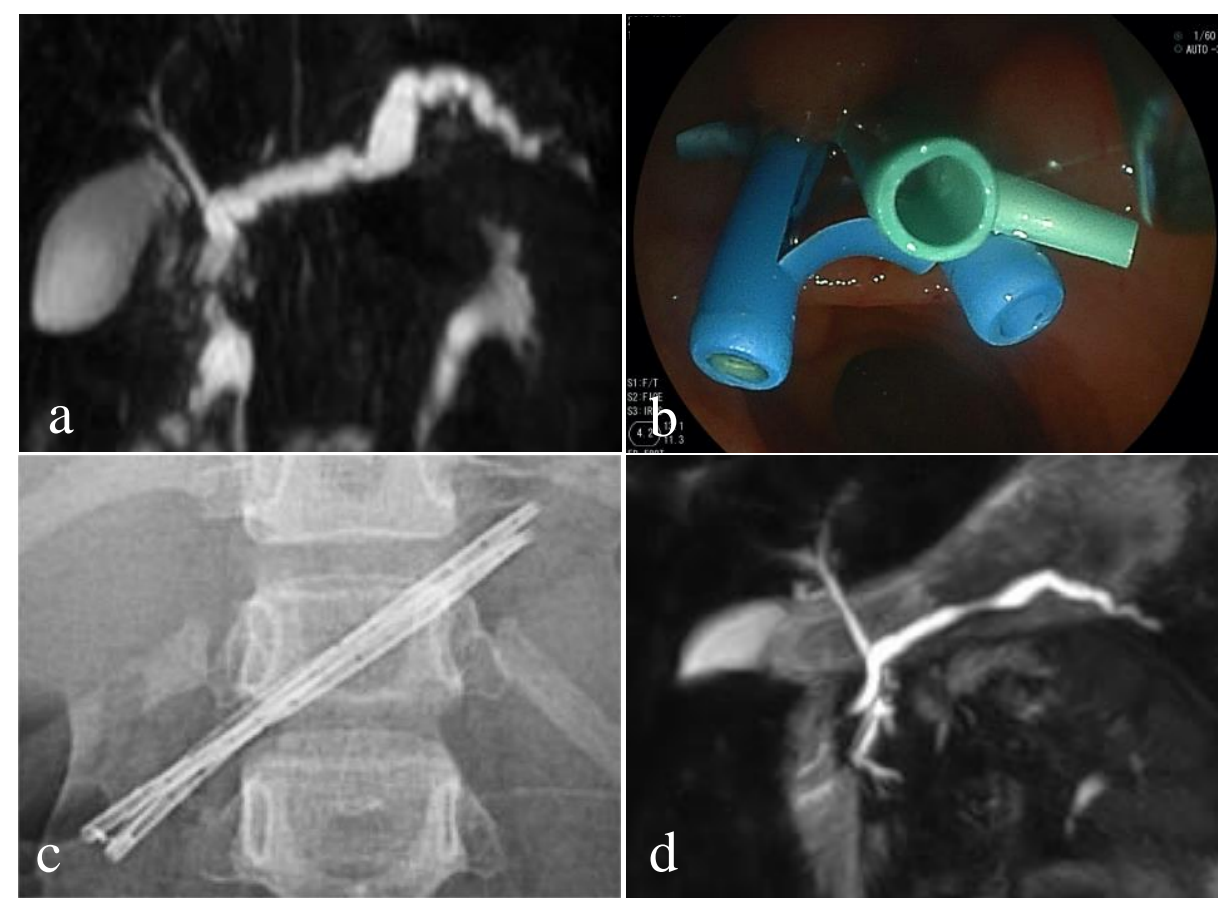

Figure 2. Multiple plastic stent placement therapy for children with hereditary pancreatitis. Magnetic resonance cholangiopancreatography (MRCP) before endoscopic treatment. The main pancreatic duct is meandering and markedly dilated (a). Endoscopic view of placement of 3 plastic stents from the minor papilla (b). Abdominal X-ray shows 3 plastic stents placed in the main pancreatic duct (c). MRCP 16 months after plastic stent removal. Dilation of the main pancreatic duct is improved (d).

\section{Conclusions}

Clinicians need to know the characteristics of ARP and CP with genetic abnormalities. Genetic testing for patients with unknown etiology is useful by analyzing CEL, CFTR, CPA1, CTRC, PRSS1, and SPINK1 genes, after the major causes of AR and CP have been excluded. In addition, testing for protective variants of PRSS2 gene is not useful clinically. The clinical usefulness of testing mutations of the genes encoding CLNN2, CTRB1, CTRB2, and PNLIP is limited due to their high frequency and narrow range of clinical symptoms. Genetic counseling prior to and after testing is required in all patients. Clinicians should carefully follow ARP and $\mathrm{CP}$ patients with genetic mutations, since they have a potentially high risk of developing pancreatic exocrine insufficiency, diabetes mellitus, and pancreatic cancer. 
Author Contributions: M.S. provided the literature review and wrote the manuscript; K.M. and S.N. provided topic outlining and manuscript editing; H.I. provided patients' clinical data and manuscript editing, and T.S. revised the manuscript for intellectual content. All authors have read and agreed to the published version of the manuscript.

Funding: This work was partially founded by a grant from the Ministry of Health, Labour, and Welfare of Japan (19FC1008 to T.S.).

Institutional Review Board Statement: The study was conducted according to the guidelines of the Declaration of Helsinki, and approved by the Institutional Review Board of Juntendo University (protocol code 2018030 and date of approval 6/4/2018).

Informed Consent Statement: Informed consent was obtained from the patient involved in the study.

Data Availability Statement: The data that support the findings of this study are available from the corresponding author, M.S., upon reasonable request.

Acknowledgments: This work was partially supported by a grant from the Ministry of Health, Labor, and Welfare of Japan under grant number 19FC1008 to T.S.

Conflicts of Interest: The authors have no conflicts of interest relevant to this article.

\section{References}

1. Whitcomb, D.C.; Gorry, M.C.; Preston, R.A.; Furey, W.; Sossenheimer, M.J.; Ulrich, C.D.; Martin, S.P.; Gates, L.K., Jr.; Amann, S.T.; Toskes, P.P.; et al. Hereditary pancreatitis is caused by a mutation in the cationic trypsinogen gene. Nat. Genet. 1996, 14, 141-145. [CrossRef] [PubMed]

2. Giefer, M.J.; Lowe, M.E.; Werlin, S.L.; Zimmerman, B.; Wilschanski, M.; Troendle, D.; Schwarzenberg, S.J.; Poh, L.J.F.; Palermo, J.; Ooi, C.Y.; et al. Early-Onset Acute Recurrent and Chronic Pancreatitis Is Associated with PRSS1 or CTRC Gene Mutations. J. Pediatr. 2017, 186, 95-100. [CrossRef] [PubMed]

3. Masamune, A.; Kikuta, K.; Hamada, S.; Nakano, E.; Kume, K.; Inui, A.; Shimizu, T.; Takeyama, Y.; Nio, M.; Shimosegawa, T. Nationwide survey of hereditary pancreatitis in Japan. J. Gastroenterol. 2018, 53, 152-160. [CrossRef] [PubMed]

4. Joergensen, M.T.; Brusgaard, K.; Cruger, D.G.; Gerdes, A.M.; Schaffalitzky de Muckadell, O.B. Genetic; epidemiological; and clinical aspects of hereditary pancreatitis, a population-based cohort study in Denmark. Am. J. Gastroenterol. 2010, 105, 1876-1883. [CrossRef] [PubMed]

5. Rebours, V.; Boutron-Ruault, M.C.; Schnee, M.; Ferec, C.; Le Marechal, C.; Hentic, O.; Maire, F.; Hammel, P.; Ruszniewski, P.; Levy, P. The natural history of hereditary pancreatitis, a national series. Gut 2009, 58, 97-103. [CrossRef] [PubMed]

6. Mayerle, J.; Sendler, M.; Hegyi, E.; Beyer, G.; Lerch, M.M.; Sahin-Toth, M. Genetics, Cell Biology, and Pathophysiology of Pancreatitis. Gastroenterology 2019, 156, 1951-1968.e1. [CrossRef]

7. Muller, N.; Sarantitis, I.; Rouanet, M.; de Mestier, L.; Halloran, C.; Greenhalf, W.; Ferec, C.; Masson, E.; Ruszniewski, P.; Levy, P.; et al. Natural history of SPINK1 germline mutation related-pancreatitis. EBioMedicine 2019, 48, 581-591. [CrossRef]

8. Comfort, M.W.; Steinberg, A.G. Pedigree of a family with hereditary chronic relapsing pancreatitis. Gastroenterology 1952, 21, 54-63. [CrossRef]

9. Gross, J.B.; Gambill, E.E.; Ulrich, J.A. Hereditary pancreatitis. Description of a fifth kindred and summary of clinical features. Am. J. Med. 1962, 33, 358-364. [CrossRef]

10. Riordan, J.R.; Rommens, J.M.; Kerem, B.; Alon, N.; Rozmahel, R.; Grzelczak, Z.; Zielenski, J.; Lok, S.; Plavsic, N.; Chou, J.L.; et al. Identification of the cystic fibrosis gene, cloning and characterization of complementary DNA. Science 1989, 245, 1066-1073. [CrossRef]

11. Cohn, J.A.; Friedman, K.J.; Noone, P.G.; Knowles, M.R.; Silverman, L.M.; Jowell, P.S. Relation between mutations of the cystic fibrosis gene and idiopathic pancreatitis. N. Engl. J. Med. 1998, 339, 653-658. [CrossRef] [PubMed]

12. Sharer, N.; Schwarz, M.; Malone, G.; Howarth, A.; Painter, J.; Super, M.; Braganza, J. Mutations of the cystic fibrosis gene in patients with chronic pancreatitis. N. Engl. J. Med. 1998, 339, 645-652. [CrossRef] [PubMed]

13. Witt, H.; Luck, W.; Hennies, H.C.; Classen, M.; Kage, A.; Lass, U.; Landt, O.; Becker, M. Mutations in the gene encoding the serine protease inhibitor; Kazal type 1 are associated with chronic pancreatitis. Nat. Genet. 2000, 25, 213-216. [CrossRef] [PubMed]

14. Felderbauer, P.; Hoffmann, P.; Einwachter, H.; Bulut, K.; Ansorge, N.; Schmitz, F.; Schmidt, W.E. A novel mutation of the calcium sensing receptor gene is associated with chronic pancreatitis in a family with heterozygous SPINK1 mutations. BMC Gastroenterol. 2003, 3, 34. [CrossRef] [PubMed]

15. Felderbauer, P.; Klein, W.; Bulut, K.; Ansorge, N.; Dekomien, G.; Werner, I.; Epplen, J.T.; Schmitz, F.; Schmidt, W.E. Mutations in the calcium-sensing receptor, a new genetic risk factor for chronic pancreatitis? Scand. J. Gastroenterol. 2006, 41, 343-348. [CrossRef]

16. Muddana, V.; Lamb, J.; Greer, J.B.; Elinoff, B.; Hawes, R.H.; Cotton, P.B.; Anderson, M.A.; Brand, R.E.; Slivka, A.; Whitcomb, D.C. Association between calcium sensing receptor gene polymorphisms and chronic pancreatitis in a US population, role of serine protease inhibitor Kazal 1type and alcohol. World. J. Gastroenterol. 2008, 14, 4486-4491. [CrossRef] 
17. Masson, E.; Chen, J.M.; Ferec, C. Overrepresentation of Rare CASR Coding Variants in a Sample of Young French Patients with Idiopathic Chronic Pancreatitis. Pancreas 2015, 44, 996-998. [CrossRef]

18. Rosendahl, J.; Witt, H.; Szmola, R.; Bhatia, E.; Ozsvari, B.; Landt, O.; Schulz, H.U.; Gress, T.M.; Pfutzer, R.; Lohr, M.; et al. Chymotrypsin C (CTRC) variants that diminish activity or secretion are associated with chronic pancreatitis. Nat. Genet. 2008, 40, 78-82. [CrossRef]

19. Whitcomb, D.C.; LaRusch, J.; Krasinskas, A.M.; Klei, L.; Smith, J.P.; Brand, R.E.; Neoptolemos, J.P.; Lerch, M.M.; Tector, M.; Sandhu, B.S.; et al. Common genetic variants in the CLDN2 and PRSS1-PRSS2 loci alter risk for alcohol-related and sporadic pancreatitis. Nat. Genet. 2012, 44, 1349-1354. [CrossRef]

20. Witt, H.; Beer, S.; Rosendahl, J.; Chen, J.M.; Chandak, G.R.; Masamune, A.; Bence, M.; Szmola, R.; Oracz, G.; Macek, M.; et al. Variants in CPA1 are strongly associated with early onset chronic pancreatitis. Nat. Genet. 2013, 45, 1216-1220. [CrossRef]

21. Fjeld, K.; Weiss, F.U.; Lasher, D.; Rosendahl, J.; Chen, J.M.; Johansson, B.B.; Kirsten, H.; Ruffert, C.; Masson, E.; Steine, S.J.; et al. A recombined allele of the lipase gene CEL and its pseudogene CELP confers susceptibility to chronic pancreatitis. Nat. Genet. 2015, 47, 518-522. [CrossRef] [PubMed]

22. Rosendahl, J.; Kirsten, H.; Hegyi, E.; Kovacs, P.; Weiss, F.U.; Laumen, H.; Lichtner, P.; Ruffert, C.; Chen, J.M.; Masso, N.E.; et al. Genome-wide association study identifies inversion in the CTRB1-CTRB2 locus to modify risk for alcoholic and non-alcoholic chronic pancreatitis. Gut 2018, 67, 1855-1863. [CrossRef] [PubMed]

23. Lasher, D.; Szabo, A.; Masamune, A.; Chen, J.M.; Xiao, X.; Whitcomb, D.C.; Barmada, M.M.; Ewers, M.; Ruffert, C.; Paliwal, S.; et al. Protease-Sensitive Pancreatic Lipase Variants Are Associated With Early Onset Chronic Pancreatitis. Am. J. Gastroenterol. 2019, 114, 974-983. [CrossRef]

24. Masamune, A.; Kotani, H.; Sorgel, F.L.; Chen, J.M.; Hamada, S.; Sakaguchi, R.; Masson, E.; Nakano, E.; Kakuta, Y.; Niihori, T.; et al. Variants That Affect Function of Calcium Channel TRPV6 Are Associated With Early-Onset Chronic Pancreatitis. Gastroenterology 2020, 158, 1626-1641.e8. [CrossRef] [PubMed]

25. Raeder, H.; Johansson, S.; Holm, P.I.; Haldorsen, I.S.; Mas, E.; Sbarra, V.; Nermoen, I.; Eide, S.A.; Grevle, L.; Bjorkhaug, L.; et al. Mutations in the CEL VNTR cause a syndrome of diabetes and pancreatic exocrine dysfunction. Nat. Genet. 2006, $38,54-62$. [CrossRef]

26. Kujko, A.A.; Berki, D.M.; Oracz, G.; Wejnarska, K.; Antoniuk, J.; Wertheim-Tysarowska, K.; Kolodziejczyk, E.; Bal, J.; Sahin-Toth, M.; Rygiel, A.M. A novel p.Ser282Pro CPA1 variant is associated with autosomal dominant hereditary pancreatitis. Gut 2017, 66, 1728-1730. [CrossRef]

27. Witt, H.; Sahin-Toth, M.; Landt, O.; Chen, J.M.; Kahne, T.; Drenth, J.P.; Kukor, Z.; Szepessy, E.; Halangk, W.; Dahm, S.; et al. A degradation-sensitive anionic trypsinogen (PRSS2) variant protects against chronic pancreatitis. Nat. Genet. 2006, 38, 668-673. [CrossRef]

28. Banks, P.A. Epidemiology; natural history; and predictors of disease outcome in acute and chronic pancreatitis. Gastrointest. Endosc. 2002, 56, S226-S230. [CrossRef]

29. Hegyi, P.; Parniczky, A.; Lerch, M.M.; Sheel, A.R.G.; Rebour, S.V.; Forsmark, C.E.; Del Chiaro, M.; Rosendahl, J.; de-Madaria, E.; Szucs, A.; et al. International Consensus Guidelines for Risk Factors in Chronic Pancreatitis. Recommendations from the working group for the international consensus guidelines for chronic pancreatitis in collaboration with the International Association of Pancreatology; the American Pancreatic Association; the Japan Pancreas Society; and European Pancreatic Club. Pancreatology 2020, 20, 579-585.

30. DeBanto, J.R.; Goday, P.S.; Pedroso, M.R.; Iftikhar, R.; Fazel, A.; Nayyar, S.; Conwell, D.L.; Demeo, M.T.; Burton, F.R.; Whitcomb, D.C.; et al. Acute pancreatitis in children. Am. J. Gastroenterol. 2002, 97, 1726-1731. [CrossRef]

31. Nydegger, A.; Couper, R.T.; Oliver, M.R. Childhood pancreatitis. J. Gastroenterol. Hepatol. 2006, 21, 499-509. [CrossRef] [PubMed]

32. Suzuki, M.; Sait, O.N.; Naritaka, N.; Nakano, S.; Minowa, K.; Honda, Y.; Ohtsuka, Y.; Yamataka, A.; Shimizu, T. Scoring system for the prediction of severe acute pancreatitis in children. Pediatr. Int. 2015, 57, 113-118. [CrossRef] [PubMed]

33. Saito, N.; Suzuki, M.; Sakurai, Y.; Nakan, O.S.; Naritaka, N.; Minowa, K.; Sai, J.K.; Shimizu, T. Genetic Analysis of Japanese Children With Acute Recurrent and Chronic Pancreatitis. J. Pediatr. Gastroenterol. Nutr. 2016, 63, 431-436. [CrossRef] [PubMed]

34. Singh, V.K.; Yadav, D.; Garg, P.K. Diagnosis and Management of Chronic Pancreatitis, A Review. JAMA 2019, 322, $2422-2434$. [CrossRef] [PubMed]

35. Ellis, I.; Lerch, M.M.; Whitcomb, D.C.; Consensus Committees of the European Registry of Hereditary Pancreatic Diseases MM-CPSGIAoP. Genetic testing for hereditary pancreatitis, guidelines for indications; counselling; consent and privacy issues. Pancreatology 2001, 1, 405-415. [CrossRef]

36. Fink, E.N.; Kant, J.A.; Whitcomb, D.C. Genetic counseling for nonsyndromic pancreatitis. Gastroenterol. Clin. North. Am. 2007, 36, 325-333. [CrossRef]

37. Howes, N.; Lerch, M.M.; Greenhalf, W.; Stocken, D.D.; Elli, S.I.; Simon, P.; Truninger, K.; Ammann, R.; Cavallini, G.; Charnley, R.M.; et al. Clinical and genetic characteristics of hereditary pancreatitis in Europe. Clin. Gastroenterol. Hepatol. 2004, 2, 252-261. [CrossRef]

38. Suzuki, M.; Shimizu, T.; Kudo, T.; Suzuki, R.; Ohtsuka, Y.; Yamashiro, Y.; Shimotakahara, A.; Yamataka, A. Usefulness of nonbreath-hold 1-shot magnetic resonance cholangiopancreatography for the evaluation of choledochal cyst in children. J. Pediatr. Gastroenterol. Nutr. 2006, 42, 539-544. [CrossRef] 
39. Lee, M.G.; Ohana, E.; Park, H.W.; Yang, D.; Muallem, S. Molecular mechanism of pancreatic and salivary gland fluid and HCO3 secretion. Physiol. Rev. 2012, 92, 39-74. [CrossRef]

40. Freedman, S.D. New concepts in understanding the pathophysiology of chronic pancreatitis. Int. J. Pancreatol. 1998, $24,1-8$.

41. Fujiki, K.; Ishiguro, H.; Ko, S.B.; Mizuno, N.; Suzuki, Y.; Takemura, T.; Yamamoto, A.; Yoshikawa, T.; Kitagawa, M.; Hayakawa, T.; et al. Genetic evidence for CFTR dysfunction in Japanese, background for chronic pancreatitis. J. Med. Genet. 2004, 41 , e55. [CrossRef] [PubMed]

42. Noone, P.G.; Zhou, Z.; Silverman, L.M.; Jowell, P.S.; Knowles, M.R.; Cohn, J.A. Cystic fibrosis gene mutations and pancreatitis risk, relation to epithelial ion transport and trypsin inhibitor gene mutations. Gastroenterology 2001, 121, 1310-1319. [CrossRef]

43. Rosendahl, J.; Land, T.O.; Bernadova, J.; Kovacs, P.; Teich, N.; Bodeker, H.; Keim, V.; Ruffert, C.; Mossner, J.; Kage, A.; et al. CFTR; SPINK1; CTRC and PRSS1 variants in chronic pancreatitis, is the role of mutated CFTR overestimated? Gut 2013, 62, 582-592. [CrossRef] [PubMed]

44. Schneider, A.; Larusch, J.; Sun, X.; Aloe, A.; Lamb, J.; Hawes, R.; Cotton, P.; Brand, R.E.; Anderson, M.A.; Money, M.E.; et al. Combined bicarbonate conductance-impairing variants in CFTR and SPINK1 variants are associated with chronic pancreatitis in patients without cystic fibrosis. Gastroenterology 2011, 140, 162-171. [CrossRef]

45. Gorry, M.C.; Gabbaizedeh, D.; Furey, W.; Gates, L.K., Jr.; Preston, R.A.; Aston, C.E.; Zhang, Y.; Ulrich, C.; Ehrlich, G.D.; Whitcom, B.D.C. Mutations in the cationic trypsinogen gene are associated with recurrent acute and chronic pancreatitis. Gastroenterology 1997, 113, 1063-1068. [CrossRef]

46. Szabo, A.; Sahin-Toth, M. Increased activation of hereditary pancreatitis-associated human cationic trypsinogen mutants in presence of chymotrypsin C. J. Biol. Chem. 2012, 287, 20701-20710. [CrossRef] [PubMed]

47. Nemoda, Z.; Sahin-Toth, M. Chymotrypsin C (caldecrin) stimulates autoactivation of human cationic trypsinogen. J. Biol. Chem. 2006, 281, 11879-11886. [CrossRef] [PubMed]

48. Kereszturi, E.; Szmola, R.; Kukor, Z.; Simon, P.; Weiss, F.U.; Lerch, M.M.; Sahin-Toth, M. Hereditary pancreatitis caused by mutation-induced misfolding of human cationic trypsinogen, a novel disease mechanism. Hum. Mutat. 2009, 30, 575-582. [CrossRef]

49. Schnur, A.; Beer, S.; Witt, H.; Hegyi, P.; Sahin-Toth, M. Functional effects of 13 rare PRSS1 variants presumed to cause chronic pancreatitis. Gut 2014, 63, 337-343. [CrossRef]

50. Hedstrom, J.; Kemppainen, E.; Andersen, J.; Jokela, H.; Puolakkainen, P.; Stenman, U.H. A comparison of serum trypsinogen-2 and trypsin-2-alpha1-antitrypsin complex with lipase and amylase in the diagnosis and assessment of severity in the early phase of acute pancreatitis. Am. J. Gastroenterol. 2001, 96, 424-430. [CrossRef]

51. Shimosegawa, T.; Kume, K.; Masamune, A. SPINK1 gene mutations and pancreatitis in Japan. J. Gastroentero. Hepatol. 2006, 21 (Suppl. 3), S47-S51. [CrossRef] [PubMed]

52. Truninger, K.; Witt, H.; Kock, J.; Kage, A.; Seifert, B.; Ammann, R.W.; Blum, H.E.; Becker, M. Mutations of the serine protease inhibitor, Kazal type 1 gene, in patients with idiopathic chronic pancreatitis. Am. J. Gastroenterol. 2002, 97, 1133-1137. [CrossRef] [PubMed]

53. Kuwata, K.; Hirota, M.; Shimizu, H.; Nakae, M.; Nishihara, S.; Takimoto, A.; Mitsushima, K.; Kikuchi, N.; Endo, K.; Inoue, M.; et al. Functional analysis of recombinant pancreatic secretory trypsin inhibitor protein with amino-acid substitution. J. Gastroenterol. 2002, 37, 928-934. [CrossRef]

54. Kiraly, O.; Wartmann, T.; Sahin-Toth, M. Missense mutations in pancreatic secretory trypsin inhibitor (SPINK1) cause intracellular retention and degradation. Gut 2007, 56, 1433-1438. [CrossRef] [PubMed]

55. Lee, Y.J.; Kim, K.M.; Choi, J.H.; Lee, B.H.; Kim, G.H.; Yoo, H.W. High incidence of PRSS1 and SPINK1 mutations in Korean children with acute recurrent and chronic pancreatitis. J. Pediatr. Gastroenterol. Nutr. 2011, 52, 478-481. [CrossRef] [PubMed]

56. Kume, K.; Masamune, A.; Mizutamari, H.; Kaneko, K.; Kikuta, K.; Sato, H.M.; Satoh, K.; Kimura, K.; Suzuki, N.; Nagasaki, Y.; et al. Mutations in the serine protease inhibitor Kazal Type 1 (SPINK1) gene in Japanese patients with pancreatitis. Pancreatology 2005, 5, 354-360. [CrossRef]

57. Oh, H.C.; Kim, M.H.; Choi, K.S.; Moon, S.H.; Park, D.H.; Lee, S.S.; Seo, D.W.; Lee, S.K.; Yoo, H.W.; Kim, G.H. Analysis of PRSS1 and SPINK1 mutations in Korean patients with idiopathic and familial pancreatitis. Pancreas 2009, 38, 180-183. [CrossRef]

58. Masamune, A.; Kume, K.; Takagi, Y.; Kikuta, K.; Satoh, K.; Satoh, A.; Shimosegawa, T. N34S mutation in the SPINK1 gene is not associated with alternative splicing. Pancreas 2007, 34, 423-428. [CrossRef]

59. Beer, S.; Zhou, J.; Szabo, A.; Keiles, S.; Chandak, G.R.; Witt, H.; Sahin-Toth, M. Comprehensive functional analysis of chymotrypsin C (CTRC) variants reveals distinct loss-of-function mechanisms associated with pancreatitis risk. Gut 2013, 62, 1616-1624. [CrossRef]

60. Masson, E.; Chen, J.M.; Scotet, V.; Le Marechal, C.; Ferec, C. Association of rare chymotrypsinogen C (CTRC) gene variations in patients with idiopathic chronic pancreatitis. Hum. Genet. 2008, 123, 83-91. [CrossRef]

61. Suzuki, M.; Minowa, K.; Isayama, H.; Shimizu, T. Acute Recurrent and Chronic Pancreatitis in Children. Pediatr Int. 2020. [CrossRef] [PubMed]

62. Fecher-Trost, C.; Wissenbach, U.; Weissgerber, P. TRPV6, From identification to function. Cell. Calcium. 2017, 67, 116-122. [CrossRef] [PubMed] 
63. Wissenbach, U.; Niemeyer, B.A.; Fixemer, T.; Schneidewind, A.; Trost, C.; Cavalie, A.; Reus, K.; Meese, E.; Bonkhoff, H.; Flockerzi, V. Expression of CaT-like; a novel calcium-selective channel; correlates with the malignancy of prostate cancer. J. Biol. Chem. 2001, 276, 19461-19468. [CrossRef]

64. Brown, E.M.; Gamba, G.; Riccardi, D.; Lombardi, M.; Butters, R.; Kifor, O.; Sun, A.; Hediger, M.A.; Lytto, N.J.; Hebert, S.C. Cloning and characterization of an extracellular $\mathrm{Ca}(2+)$-sensing receptor from bovine parathyroid. Nature 1993, 366, 575-580. [CrossRef] [PubMed]

65. Racz, G.Z.; Kittel, A.; Riccardi, D.; Case, R.M.; Elliott, A.C.; Varga, G. Extracellular calcium sensing receptor in human pancreatic cells. Gut 2002, 51, 705-711. [CrossRef] [PubMed]

66. Kukor, Z.; Toth, M.; Sahin-Toth, M. Human anionic trypsinogen, properties of autocatalytic activation and degradation and implications in pancreatic diseases. Eur. J. Biochem. 2003, 270, 2047-2058. [CrossRef] [PubMed]

67. Jancso, Z.; Hegyi, E.; Sahin-Toth, M. Chymotrypsin Reduces the Severity of Secretagogue-Induced Pancreatitis in Mice. Gastroenterology 2018, 155, 1017-1021. [CrossRef]

68. Liu, Q.Y.; Abu-El-Haij, A.M.; Husain, S.Z.; Barth, B.; Bellin, M.; Fishman, D.S.; Freedman, S.D.; Gariepy, C.E.; Giefer, M.J.; Gonska, T.; et al. Risk Factors for Rapid Progression From Acute Recurrent to Chronic Pancreatitis in Children, Report from INSPPIRE. J. Pediatr. Gastroenterol. Nutr. 2019, 69, 206-211. [CrossRef]

69. Rebours, V.; Boutron-Ruault, M.C.; Schnee, M.; Ferec, C.; Maire, F.; Hammel, P.; Ruszniewski, P.; Levy, P. Risk of pancreatic adenocarcinoma in patients with hereditary pancreatitis, a national exhaustive series. Am. J. Gastroenterol. 2008, 103, 111-119. [CrossRef]

70. Shelton, C.A.; Umapathy, C.; Stello, K.; Yadav, D.; Whitcomb, D.C. Hereditary Pancreatitis in the United States, Survival and Rates of Pancreatic Cancer. Am. J. Gastroenterol. 2018, 113, 1376. [CrossRef]

71. Lasson, A.; Ohlsson, K. Consumptive coagulopathy; fibrinolysis and protease-antiprotease interactions during acute human pancreatitis. Thromb. Res. 1986, 41, 167-183. [CrossRef]

72. Dumnicka, P.; Maduzia, D.; Ceranowicz, P.; Olszanecki, R.; Drozdz, R.; Kusnierz-Cabala, B. The Interplay between Inflammation; Coagulation and Endothelial Injury in the Early Phase of Acute Pancreatitis, Clinical Implications. Int. J. Mol. Sci. 2017, 18, 354. [CrossRef] [PubMed]

73. Gray, E.; Hogwood, J.; Mulloy, B. The anticoagulant and antithrombotic mechanisms of heparin. Handb. Exp. Pharmacol. 2012, 207, 43-61.

74. Finotti, P.; Manente, S. Heparin-induced structural and functional alterations of bovine trypsin. Biochim. Biophys. Acta. 1994, 1207, 80-87. [CrossRef]

75. Struss, D.; Storck, J.; Zimmermann, R.E. The inhibition of thrombin and chymotrypsin by heparin-cofactor II. Thromb. Res. 1992, 68, 45-56. [PubMed]

76. Wolosowicz, N.; Prokopowicz, J.; Gabryelewicz, A. The inhibitory effect of heparin on trypsinogen activation with enterokinase. Acta. Hepatogastroenterol. 1977, 24, 368-371.

77. Bottino, R.; Bertera, S.; Grupillo, M.; Melvin, P.R.; Humar, A.; Mazariegos, G.; Moser, A.J.; Walsh, R.M.; Fung, J.; Gelrud, A.; et al. Isolation of human islets for autologous islet transplantation in children and adolescents with chronic pancreatitis. J. Transplant. 2012, 2012, 642787. [CrossRef] [PubMed]

78. Wilson, G.C.; Sutton, J.M.; Salehi, M.; Schmulewitz, N.; Smith, M.T.; Kucera, S.; Choe, K.A.; Brunner, J.E.; Abbott, D.E.; Sussman, J.J.; et al. Surgical outcomes after total pancreatectomy and islet cell autotransplantation in pediatric patients. Surgery 2013, 154, 777-783. [CrossRef]

79. Chinnakotla, S.; Radosevic, H.D.M.; Dunn, T.B.; Bellin, M.D.; Freeman, M.L.; Schwarzenberg, S.J.; Balamurugan, A.N.; Wilhelm, J.; Bland, B.; Vickers, S.M.; et al. Long-term outcomes of total pancreatectomy and islet auto transplantation for hereditary/genetic pancreatitis. J. Am. Coll. Surg. 2014, 218, 530-543. [CrossRef]

80. Agarwal, J.; Reddy, D.N.; Talukdar, R.; Lakhtakia, S.; Ramchandani, M.; Tandan, M.; Gupta, R.; Pratap, N.; Rao, G.V. ERCP in the management of pancreatic diseases in children. Gastrointest. Endosc. 2014, 79, 271-278. [CrossRef]

81. Nabi, Z.; Reddy, D.N. Advanced Therapeutic Gastrointestinal Endoscopy in Children-Today and Tomorrow. Clin. Endosc. 2018, 51, 142-149. [CrossRef] [PubMed]

82. Issa, Y.; Bruno, M.J.; Bakker, O.J.; Besselink, M.G.; Schepers, N.J.; van Santvoort, H.C.; Gooszen, H.G.; Boermeester, M.A. Treatment options for chronic pancreatitis. Nat. Rev. Gastroenterol. Hepatol. 2014, 11, 556-564. [CrossRef] [PubMed]

83. Majumder, S.; Chari, S.T. Chronic pancreatitis. Lancet 2016, 387, 1957-1966. [CrossRef]

84. Kargl, S.; Kienbauer, M.; Duba, H.C.; Schofl, R.; Pumberger, W. Therapeutic step-up strategy for management of hereditary pancreatitis in children. J. Pediatr. Surg. 2015, 50, 511-514. [CrossRef]

85. Costamagna, G.; Bulajic, M.; Tringali, A.; Pandolfi, M.; Gabbrielli, A.; Spada, C.; Petruzziello, L.; Familiari, P.; Mutignani, M. Multiple stenting of refractory pancreatic duct strictures in severe chronic pancreatitis, long-term results. Endoscopy 2006, 38, 254-259. [CrossRef]

86. Matsubara, S.; Sasahira, N.; Isayama, H.; Takahara, N.; Mizuno, S.; Kogur, E.H.; Yamamoto, N.; Nakai, Y.; Tada, M.; Koike, K. Prospective pilot study of fully covered self-expandable metal stents for refractory benign pancreatic duct strictures, long-term outcomes. Endosc. Int. Open 2016, 4, E1215-E1222.

87. Tringali, A.; Bov, E.V.; Vadala di Prampero, S.F.; Boskoski, I.; Familiari, P.; Perri, V.; Costamagna, G. Long-term follow-up after multiple plastic stenting for refractory pancreatic duct strictures in chronic pancreatitis. Endoscopy 2019, 51, 930-935. [CrossRef] 